\title{
Pull-out suture technique and micro-bone anchor fixation: a comparison of two methods in the treatment of nonosseous mallet finger injuries
}

\section{Kemik avulsyonu olmayan çekiç parmak deformitesinin tedavisinde, Pull-out sütür tekniği ile mikro-kemik çapa fiksasyonu yöntemlerinin karşılaştırılması}

\author{
Kaan Güirlbuiz
}

Department of Orthopedics and Traumatology, Kayseri Training and Research Hospital, Kayseri, Turkey

Corresponding author: Kaan Gürbüz, MD, Department of Orthopedics and Traumatology, Kayseri Training and Research Hospital, Kayseri, Turkey.

E-mail: drkagangurbuz@gmail.com

Received/Accepted: December 09, 2018 /June 26, 2019

Conflict of interest: There is not a conflict of interest.

\section{SUMMARY}

Objective: Mallet finger is a flexion deformity that results from injury to the extensor mechanism at the base of the distal phalanx. It can involve either a bony avulsion injury of the distal phalanx or a rupture of the extensor tendon with no bony involvement.

The aim of this study was to compare the surgical and clinical outcomes of patients who underwent the pull-out suture technique versus micro-bone anchor fixation of non-osseous mallet finger.

Method: A retrospective analysis of 56 patients between 2011 and 2016 was conducted. Patients were separated into two groups according to surgical technique, Group 1 (pull-out suture technique ) including 23 patients and Group 2 (micro-bone anchor fixation ) including 33 patients. The Quick Disabilities of the Arm, Shoulder, and Hand (Q-DASH) score, catastrophizing pain scale (PCS), visual analog scale (VAS) pain score, and time to return to work were assessed. Crawford's criteria were used to evaluate the functional results.

Results: No significant difference was observed in the Crawford classification and pain score between the groups, whereas the Q-DASH score and the time to return to daily activities were significantly different in the micro-bone anchor fixation group.

Conclusions: Both techniques are effective operative treatment options for non-osseous mallet finger. However, compared with the pull-out suture technique, micro-bone anchor fixation provides better results in terms of some clinical parameters.

Keywords: Mallet finger, pull-out technique, non-osseous mallet finger, micro-bone anchor
Kaan Gürbüz

ORCID IDs of the authors: K.G. 0000-0002-0144-5517 
Yöntem: 2011-2016 yılları arasında 56 hastanın retrospektif analizi yapıldı. Cerrahi tekniğe göre hastalar iki gruba ayrıldı. Grup 1'de pull-out suture tekniği uygulanan 23 hasta, Grup 2'de ise mikro-kemik çapa fiksasyonu yapılan 33 hasta vardır. Kol, Omuz ve El (Q-DASH) skoru, ağrı felaketi ölçeği (PCS), görsel analog skala (VAS) ağrı skoru ve işe dönme süresi değerlendirildi. Fonksiyonel sonuçları değerlendirmek için Crawford'ın kriterleri kullanıldı.

Bulgular: Crawford sınıflandırmasında ve ağrı skorunda gruplar arasında anlamlı bir fark gözlenmedi ( $<<0.05)$, QDASH skoru ve günlük aktivitelere dönme süresi mikro-kemik çapa fiksasyon grubunda anlamlı derecede farklıydı.

Sonuç: Her iki teknik de kemik avülse olmayan çekiç parmak deformitesi için etkin cerrahi tedavi seçeneklerdir. Bununla birlikte, pull-out sutur tekniği ile karşılaştırıldığında, mikro-kemik çapa fiksasyonu bazı klinik parametreler açısından daha iyi sonuçlar sağlar.

Anahtar sözcükler: Çekiç parmak, pull-out teknik, kemik avulse olmayan çekiç parmak

\section{INTRODUCTION}

Mallet finger is a flexion deformity that results from injury to the extensor mechanism at the base of the distal phalanx. ${ }^{1-3}$ It can involve either a bony avulsion injury of the distal phalanx or a rupture of the extensor tendon with no bony involvement. ${ }^{1,3}$ Injury often occurs with the force of hyperflexion of the distal interphalangeal joint as a result of a vertical load on the fingertip. ${ }^{1}$ If not managed correctly, mallet finger injuries may progress to form a 'swan neck' deformity of the finger. ${ }^{4,5}$ This type of injuries are more common in men, with the middle finger of the dominant hand. ${ }^{4,5}$ Closed mallet finger injuries are treated full-time with an immobilization splint in the extension or slight hyperextension position for 68 weeks. ${ }^{6-8}$

Doyle's classification is most commonly used for managing mallet finger deformities (Table 1)., Type I mallet finger injuries are observed in patients who have failed non-surgical treatment, and surgical management is recommended in type II, III, and IV injuries. ${ }^{3,5,8}$
Many operative techniques have been recommended for mallet finger injuries with bone components, such as open reduction and Kirschner-wire (K-wire) fixation, tension band wire, pull-out steel wires, screw fixation, percutaneous pin fixation, percutaneous extension block pinning, percutaneous compression fixation pins, mini external fixators, bone anchor systems, and hook plate fixation. ${ }^{1-5}$ However, there are no clearly established criteria for satisfactory results. ${ }^{4,5}$

Surgical treatment can also be performed in patients who have been neglected or who have not managed to fit the finger splint in mallet finger deformities that occurred because of a rupture of the extensor tendon from the distal phalanx insertion without a bone component. ${ }^{2,5,8,9}$

In this study, the clinical outcomes of patients who underwent the pull-out suture technique with extension block pinning versus micro-bone anchor fixation of non-osseous mallet finger injuries were compared.

Table 1: Doyle's classification of mallet finger injuries.

\begin{tabular}{|l|l|}
\hline Type & Description \\
\hline I & Closed injury, with or without small avulsion fracture \\
\hline II & Open injury (laceration) \\
\hline III & Open injury (deep abrasion involving skin and tendon substance) \\
\hline IV & Mallet fracture \\
\hline IVa & Distal phalanx physical injury (pediatric) \\
\hline IVb & Fracture fragment involving $20 \%-50 \%$ of the articular surface \\
\hline IVc & Fracture fragment $>50 \%$ of the articular surface \\
\hline
\end{tabular}

\section{MATERIAL AND METHODS}

56 patients, who underwent surgical treatment for mallet finger deformities between 2011 and 2015 were retrospectively evaluated. Patients were separated into two groups according to surgical technique. Group 1 included 23 patients (10 males, 13 females; 12 right hands, 11 left hands; mean age 41 years; range 18-64 years) who underwent pull-out suture technique, whereas Group 2 included 33 patients $(17$ males, 16 females; 16 right hands, 17 left hands; mean age 48 years; range 21-76 years) who underwent micro-bone anchor fixation. 
The index finger was affected in 1 patient $(4.3 \%)$, the middle finger in 5 patients $(21.7 \%)$, the fourth finger in 12 patients $(52.3 \%)$, and the small finger in 5 patients $(21.7 \%)$ in Group 1 . The middle finger was affected in 13 patients $(39.4 \%)$, the fourth finger in 7 patients $(21.2 \%)$, and the small finger in 13 patients (39.4\%) in Group 2.

All the patients were considered to be eligible for surgical intervention because of the time elapsed since the injury, or the absence or ineffectiveness of the previous treatment. Radiographs were taken preoperatively and postoperatively. Patients were excluded from the study if they had pre-existing degenerative changes involving the distal interphalangeal (DIP) joint or mallet fracture of the distal phalanx or if they had previously been surgically treated for a mallet fracture.

The Quick Disabilities of the Arm, Shoulder, and Hand (Q-DASH) score, catastrophizing pain scale (PCS), visual analog scale (VAS) pain score, and time to return to work were assessed. ${ }^{10,11}$ The Crawford's criteria were used to evaluate the functional results (excellent, good, fair, and poor). ${ }^{12}$ The study was approved by the local
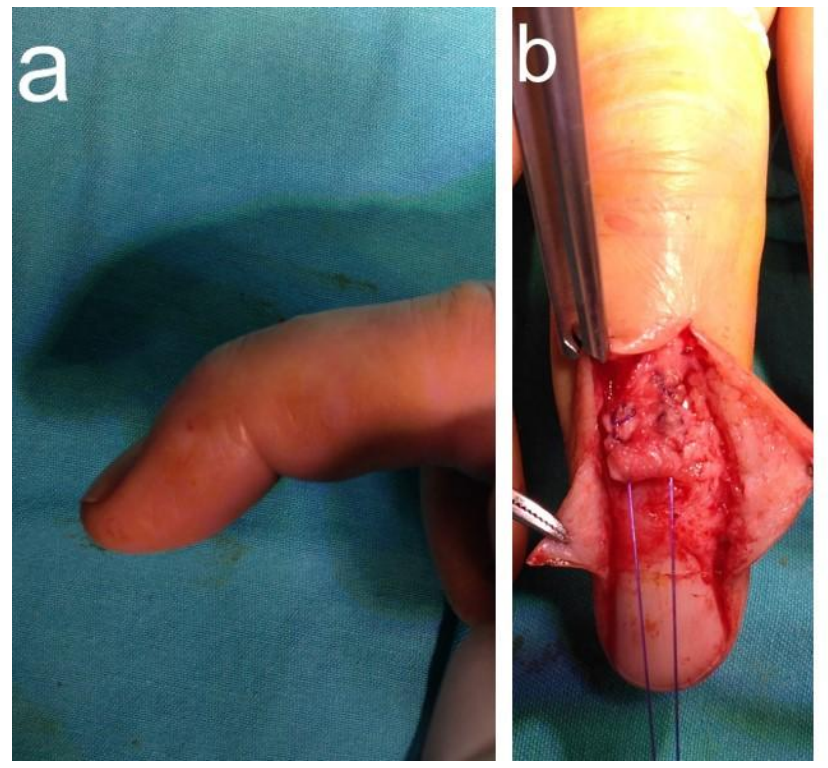

Fig. 1: Images of the pull-out suture technique with extension block pinning of non-osseous mallet finger deformity; (a) preoperative image, (b) intra-operative image, and (c, d) postoperative image.

\subsubsection{Anchor fixation surgical technique}

The surgical procedure was performed under digital block anesthesia using a digital tourniquet. A dorsal Z-shaped incision was made at the distal interphalangeal (DIP) joint. The dissection was limited distally to avoid surgical trauma to the germinal matrix. The extensor tendon was exposed, and the anchor $(1.8 \mathrm{~mm}$ in diameter and $3.2 \mathrm{~mm}$ in length) with its attached 4-0

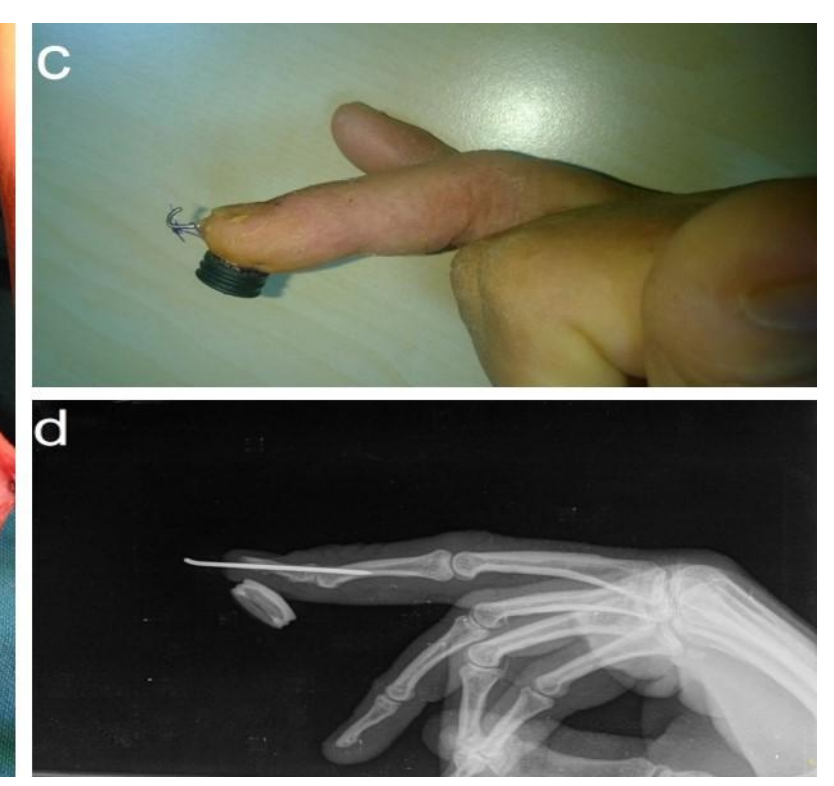

institutional review board, and all patients provided informed consent.

\subsection{Surgical technique}

\subsubsection{Pull-out suture surgical technique}

The surgical procedure was performed under digital block anesthesia using a digital tourniquet. A dorsal Z-shaped incision was made at the distal interphalangeal (DIP) joint. The dissection was limited distally to avoid surgical trauma to the germinal matrix. The extensor tendon was exposed, and a Kessler mattress type suture with 4-0 polypropylene was passed from it. Two needles were then passed through the distal phalanx. Then, the suture was inserted through the needle, and the suture was pulled out. The polypropylene suture was passed through the distal phalanx in a dorsal to the palmar direction. Then the DIP joint was fixed with $1.0 \mathrm{~mm}$ diameter K-wire. Finally, a knot was tied over the distal palmar phalanx (Fig. 1). The K-wire was removed in all patients 4-5 weeks after the procedure. Active and passive range of motion exercises were started immediately after removal of the K-wire. 

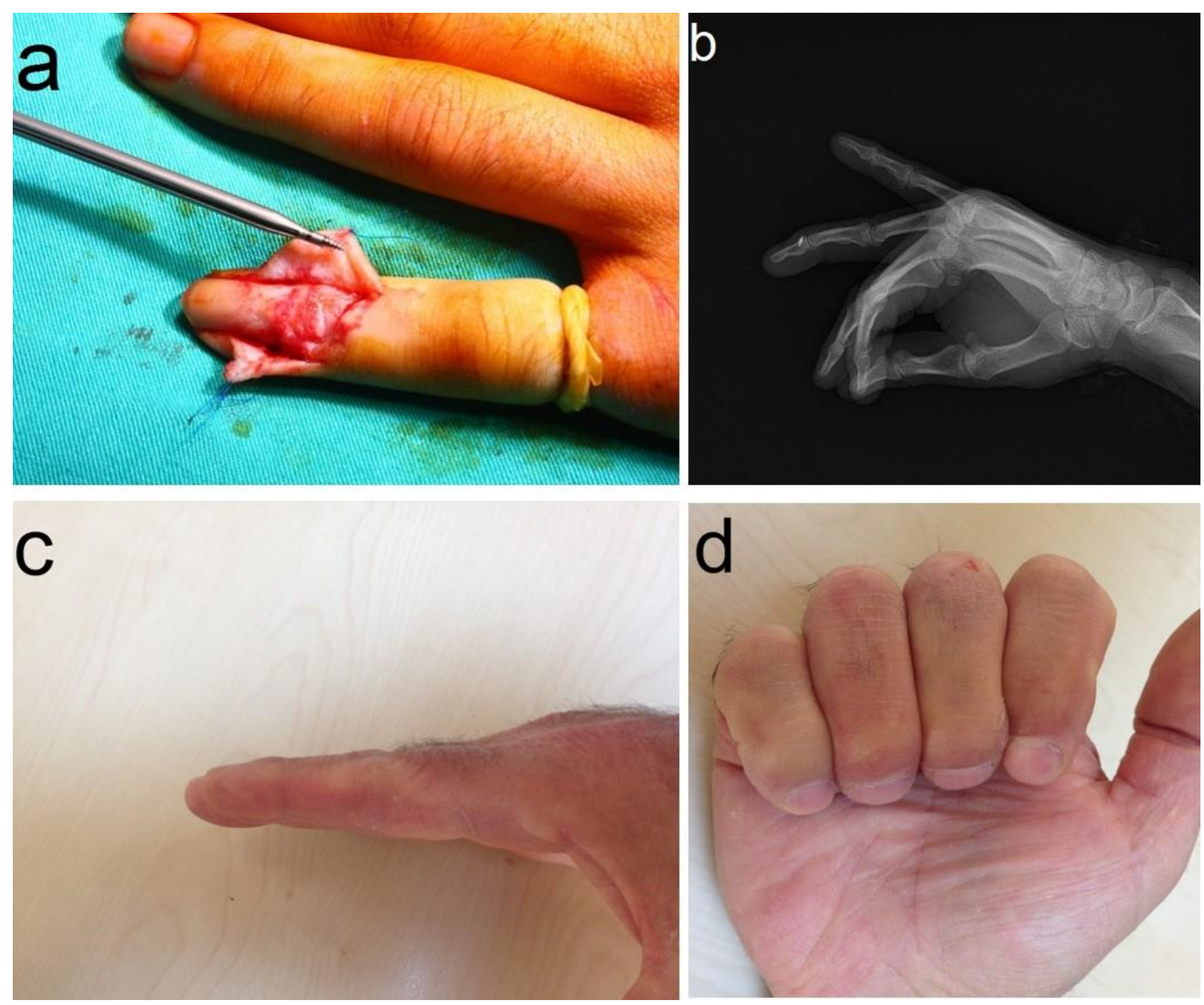

Fig. 2: Images of micro-bone anchor fixation of non-osseous mallet finger deformity; (a) intra-operative image, (b) postoperative radiograph, and $(c, d)$ functional results of the right ring finger at postoperative 14 months.

\subsection{Statistical analysis}

Statistical analysis was performed using IBM SPSS Statistics 21.0 (IBM, Armonk, NY, USA). The frequency analysis was performed to analyze categorical variables. The data were expressed as numbers and percentages. The paired Student's $t$ test and Pearson $\chi^{2}$ test were used to comparing categorical data groups. $P<0.05$ was considered statistically significant.

\section{RESULTS}

The characteristics of the patients and clinical outcomes are presented in Table 2. According to Doyle classification, all lesions were of type I.

The splinting was unsuccessful in 10 patients (43.4\%) in Group 1 and 13 patients (39.3\%) in Group 2. Thirteen $(56.6 \%)$ and twenty patients
$(60.7 \%)$ had not received any treatment in Group 1 and Group 2, respectively.

Nineteen patients $(82.6 \%)$ had the disease in the dominant hand in Group 1 and sixteen patients (48.4\%) in Group $2(\mathrm{p}=0.412)$. The causes of injury in the study population were as follows: simple fall in 27 patients, home accident in 12 patients, work accident in 8 patients, door injury in 7 patients, and sports injury in 2 patients.

The mean time from injury to surgery was 28.1 days (range, 21-42 days) and 23.9 days (range, 12-43 days) in Group 1 and Group 2, respectively $(\mathrm{p}=0.058)$. The mean duration of follow-up was 13.9 months (range, 7-26 months) and 11.5 months (range, 7-25 months) in Group 1 and Group 2, respectively $(\mathrm{p}=0.271)$. The mean time for patients to return to daily activity was $\mathbf{6 . 6}$ 
weeks (range, 5-8 weeks) in Group 1 and 5.1 weeks (range, 4-8 weeks) in Group 2 (p = 0.0001).

The mean Q-DASH score at final follow-up was 6.2 (range, 4-12) in Group 1 and 7.8 (range, 4-12) in Group $2(\mathrm{p}=0.008)$. The mean VAS score was 0.09 (range, 0-1) in Group 1 and 0.12 (range, 0-1) in Group $2(\mathrm{p}=0.664)$. The mean PCS was 6 (range, 1-10) in Group 1 and 4.6 (range, 3-11) in Group $2(p=0.068)$ (Table 3).

Table 2: Demographic characteristics and clinical outcomes.

\begin{tabular}{|c|c|c|c|}
\hline & $\begin{array}{l}\text { Group } 1 \\
(\mathrm{n}=23)\end{array}$ & $\begin{array}{l}\text { Group } 2 \\
(\mathrm{n}=33)\end{array}$ & $P$ Value \\
\hline Mean age, years, mean (range) & $41(18-64)$ & $48(21-76)$ & 0.1962 \\
\hline \multicolumn{4}{|l|}{ Sex } \\
\hline Female & 13 & 16 & \multirow[t]{2}{*}{0.771} \\
\hline Male & 10 & 17 & \\
\hline $\begin{array}{l}\text { Side of involvement } \\
\text { Right } \\
\text { Left }\end{array}$ & $\begin{array}{l}12 \\
11\end{array}$ & $\begin{array}{l}16 \\
17\end{array}$ & 0.146 \\
\hline $\begin{array}{l}\text { Interventions/digit } \\
\text { Index } \\
\text { Middle } \\
\text { Ring } \\
\text { Little }\end{array}$ & $\begin{array}{l}1 \\
5 \\
12 \\
5\end{array}$ & $\begin{array}{l}- \\
13 \\
7 \\
13\end{array}$ & 0.405 \\
\hline Dominant extremity injury, (\%) & $19(82.6)$ & $16(48.4)$ & 0.412 \\
\hline Time from injury to surgery, days (range) & $28.1(21-42)$ & $23.9(12-43)$ & 0.058 \\
\hline Follow-up, months (range) & $13.9(7-26)$ & $11.5(7-25)$ & 0.271 \\
\hline \multicolumn{4}{|l|}{ Crawford classification, } \\
\hline Excellent & 11 & 15 & \multirow{4}{*}{0.855} \\
\hline Good & 12 & 18 & \\
\hline Fair & - & - & \\
\hline Poor & - & - & \\
\hline $\begin{array}{l}\text { Returned to pre-injury daily activities, } \\
\text { weeks (range) }\end{array}$ & $6.6(5-8)$ & $5.1(4-8)$ & 0.0001 \\
\hline DIP extensor lag $\left(^{\circ}\right)$ & $10.6(6-16)$ & $4.9(4-8)$ & 0.0001 \\
\hline Flexion $\operatorname{arc}\left(^{\circ}\right)$ & $74.5(65-88)$ & $83(74-90)$ & 0.0001 \\
\hline
\end{tabular}


Table 3: Functional results of two techniques.

\begin{tabular}{|l|l|l|c|}
\hline & \multicolumn{1}{|c|}{ Preoperative } & \multicolumn{1}{|c|}{ Postoperative } & $P$ Value \\
\hline VAS pain & $6.3(5-9)$ & $0.09(0-1)$ & 0.0001 \\
Group 1 & $6.8(5-9)$ & $0.12(0-1)$ & 0.0001 \\
Group 2 & & & $0.664^{\mathrm{a}}$ \\
\hline GCS score & $23.2(16-35)$ & $6(1-10)$ & 0.0001 \\
Group 1 & $27.6(9-35)$ & $4.6(3-11)$ & 0.0001 \\
Q-DASH & & & $0.068^{\mathrm{a}}$ \\
Group 1 & $33.3(24-44)$ & $6.2(4-12)$ & 0.0001 \\
Group 2 & $31.9(22-44)$ & & 0.0001 \\
& & & $0.008^{\mathrm{a}}$ \\
\hline
\end{tabular}

Abbreviations: VAS, visual analog scale; PCS, Pain Catastrophizing Scale; Q-DASH, Quick Disabilities of the Arm, Shoulder, and Hand score.

${ }^{\text {a }}$ Statistical results of postoperative values between Group 1 and Group 2.

The mean extensor lag of the DIP joint at final follow-up was $10.6^{\circ}$ (range, $6^{\circ}-16^{\circ}$ ) in Group 1 and $4.9^{\circ}$ (range, $\left.4^{\circ}-8^{\circ}\right)$ in Group $2(\mathrm{p}=0.0001)$. The mean flexion arc of the DIP joint was $74.5^{\circ}$ (range, $65^{\circ}-88^{\circ}$ ) in Group 1 and $83^{\circ}$ (range, $74^{\circ}-$ $\left.90^{\circ}\right)$ in Group $2(\mathrm{p}=0.0001)$.

According to Crawford's evaluation criteria, 11 and 12 patients showed excellent and good results, respectively in Group 1, and 15 and 18 patients showed excellent and good results, respectively in Group $2(\mathrm{p}=0.855)$.
Nail deformity developed in one patient in Group 1 and two patients in Group 2 (Fig. 3). Radiographs showed moderate dorsal bony prominence in one patient in Group 1. Mild DIP joint degeneration was observed in two patients each in Group 1 and Group 2. Superficial incision site infection was observed in one patient in Group 2 which resolved with antibiotic therapy and wound care. Patients did not complain of pain after releasing the $\mathrm{K}$-wire and immobilization. 

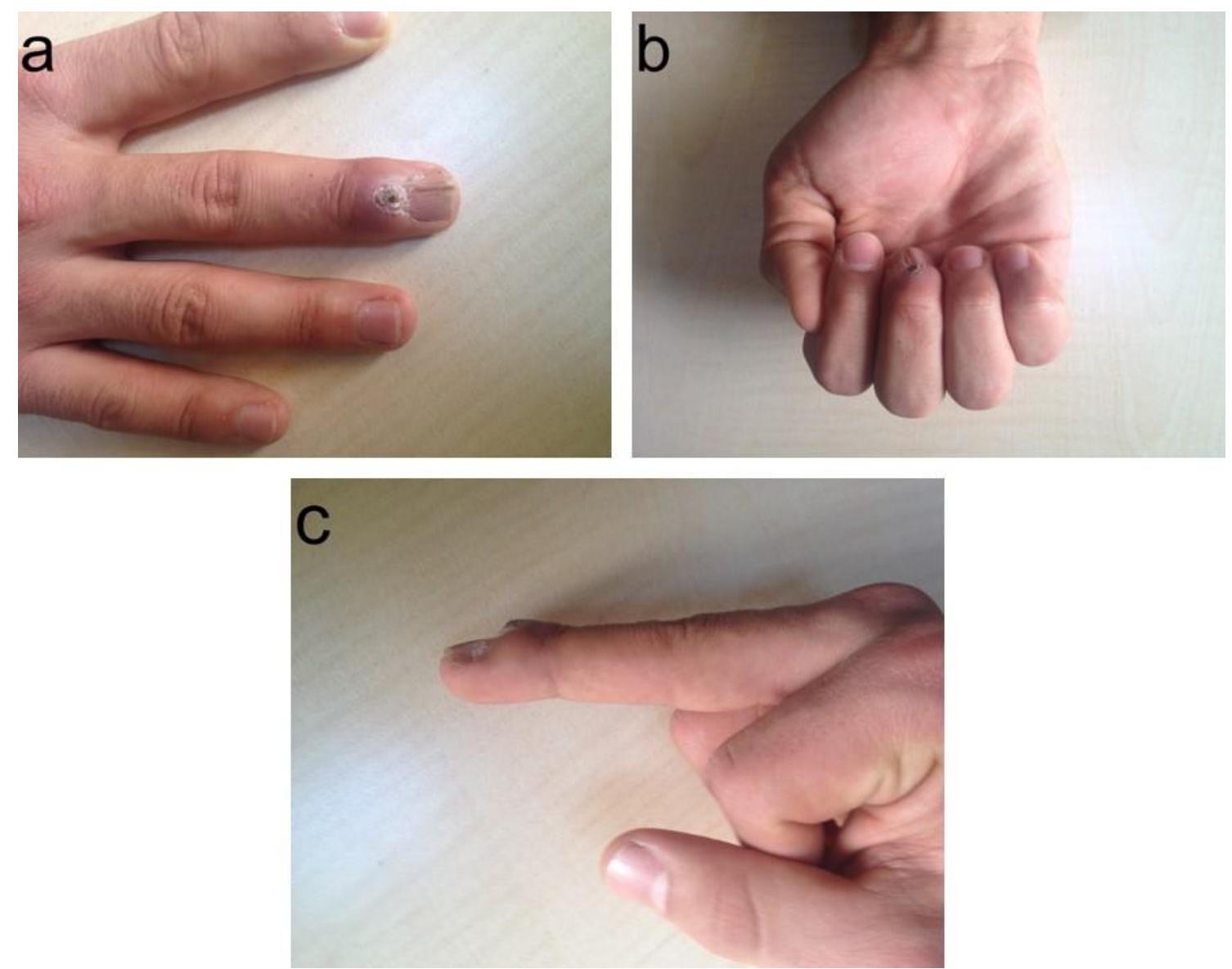

Fig. 3: (a, b, c) Images and functional results of the right middle finger nail deformity that developed after performing micro-bone anchor fixation.

\section{DISCUSSION}

In this study, comparison of the surgical outcomes in non-osseous mallet finger injuries between the pull-out suture technique and micro-bone anchor fixation were evaluated. Although there were not significant differences in VAS, PCS, and Crawford classification between the groups, the Q-DASH score and the mean time to return to daily activities were significantly different between the two groups. Furthermore, in the degrees of DIP extensor lag and flexion arc between the groups was statistically significant.

Numerous conservative and surgical methods have been described for the treatment of mallet finger deformities. ${ }^{1-7}$ The primary goal in all treatment methods is the restoration of the continuity of injured tendons with a stable DIP joint and complete, painless finger motion. ${ }^{13}$ Although many studies have analyzed the role of various surgical methods in the treatment of mallet finger deformities, few studies have compared different methods, particularly as per Doyle's classification type I. ${ }^{2,8,9}$
In some cases, an avulsion fracture occurs at the insertion of the extensor tendon on the distal phalanx, which is known as 'osseous mallet finger' injury. ${ }^{14}$ It is generally agreed upon by most surgeons that if the avulsed fragment is larger than one-third of the articular surface, a surgical procedure is recommended, and numerous techniques have been described [5,8]. According to Handoll and Vaghela, there is insufficient evidence to support surgical over nonsurgical treatment for bony mallet fingers. ${ }^{14}$ However, Kalainov et al. ${ }^{15}$ reported that closed and displaced mallet finger fractures with greater than one-third articular surface damage could be treated non-operatively with negligible pain and return of good function.

In other cases, the extensor tendon is ruptured from its insertion on the distal phalanx, which is known as 'non-osseous mallet finger' injury. ${ }^{14}$ Several surgeons consider that for acute nonosseous mallet finger injuries, it is possible to obtain an excellent outcome by continuous splinting of the DIP in the neutral extension or slight hyperextension position for 6-8 weeks. ${ }^{3,6,7,8}$ Moreover, for the treatment of chronic non- 
osseous mallet finger injuries, some authors consider splinting to be successful for up to several months post-injury. ${ }^{6,16}$ As with osseous mallet finger injuries, there is insufficient evidence to support surgical over the non-surgical treatment of non-osseous mallet finger injuries. $^{2,5,6,8,9,14}$ There are some authors who have reported that successful results could be obtained with conservative treatment of type IVb and IVc mallet finger deformities, according to the Doyle classification as well as surgical treatment of type $\mathrm{I}^{2,8,9,15}$

Nakamura et al. ${ }^{9}$ used surgical procedures to treat type I and II Doyle classification mallet finger injuries to achieve early finger mobilization. They reported that 15 patients achieved $58^{\circ}$ of DIP joint range of motion and $6^{\circ}$ extension lag at the mean 1-year follow-up.

Ulusoy et $\mathrm{al}^{2}$ showed results of treatment in 19 patients with neglected mallet finger deformities; 11 cases were typed I and II according to Doyle classification, and 8 cases were type IV. The results were assessed at the mean duration of 16 months, average flexion was $74^{\circ}$, and functional results were considered very good in 14 and good in 5 cases according to Crawford criteria.

There are some disadvantages of mallet finger surgeries, such as difficulty in achieving earlier mobilization; the incidence of nail deformity, joint incongruity, skin necrosis, and infection; and limitation of flexion of the DIP joint. ${ }^{4,5,14,17,18}$ Kang et al. $^{19}$ reported that postoperative complications of surgically treated mallet finger deformities developed in $41 \%$ of patients. In this study, postoperative complications developed in 17\% in Group 1 and 15\% in Group 2.

The limitations of this study include its mean extensor lag of the DIP joint and mean flexion arc of the DIP joint was measured by the same person who performs the surgery which was vulnerable to bias, leaving some doubt as to its value as an outcome measure. Thus, the main focus of our analysis has been with regarding the The Quick Disabilities of the Arm, Shoulder, and Hand (QDASH) score, pain catastrophizing scale (PCS), visual analogue scale (VAS) pain score, and time to return to work. Another limitation of this study is the short duration of follow-up. Longer-term follow-up with regards to the development of clinical and radio-graphical signs of arthritis would be of interest, and are unfortunately outside the scope of this study.

In conclusion, the pull-out suture technique with extension block pinning as well as micro-bone anchor fixation with orthosis are simple and effective methods with low rates of complications in the treatment of non-osseous mallet finger injuries. However, compared with the pull-out suture technique, micro-bone anchor fixation has given better results in terms of some clinical parameter.

\section{REFERENCES}

1. Bloom JM, Khouri JS, Hammert WC. Current concepts in the evaluation and treatment of mallet finger injury. Plast Reconstr Surg. 2013;132:560-566.

2. Ulusoy MG, Karalezli N, Kocer U, et al. Pull-in suture technique for the treatment of mallet finger. Plast Reconstr Surg. 2006;118:696-702.

3. Doyle JR. Extensor tendons-acute injuries. In: Green DP, Hotchkiss RN, Pederson WC, editors. Operative hand surgery. 4th ed. New York: Churchill Livingstone; 1999. p. 1950-87.

4. Ulkur E, Acikel C, Ergun O, Celikoz B. Repair of chronic mallet finger deformity using Mitek micro arc bone anchor. Ann Plast Surg. 2005;54:393-396.

5. $\mathrm{Lu} \mathrm{J}$, Jiang J, Xu L, Xu W, Xu J. Modification of the pull-in suture technique for mallet finger. Ann Plast Surg. 2013;70:30-33.

6. Altan E, Alp NB, Baser R, Yalçın L. SoftTissue Mallet Injuries: A Comparison of Early and Delayed Treatment. J Hand Surg Am. 2014;39:1982-1985.

7. Gruber JS, Bot AG, Ring D. A prospective randomized controlled trial comparing night splinting with no splinting after treatment of mallet finger. Hand NY. 2014;9:145-150.

8. Georgescu AV, Capota IM, Matei IR. A new surgical treatment for mallet finger deformity: de-epithelialised pedicled skin flap technique. Injury 2013;44:351-355.

9. Nakamura K, Nanjo B. Reassessment of surgery for mallet fracture. Plast reconstr surg. 1994;93:141-149.

10. Süren M, Okan I, Gökbakan AM, et al. Factors associated with the pain catastrophizing scale and validation in a sample of the Turkish population. Turk $\mathbf{J}$ Med Sci. 2014;44:104-108.

11. Katz J, Melzack R. Measurement of pain. Surg Clin North Am. 1999;79:231-252.

12. Crawford GP. The molded polythene splint for mallet finger deformities. J Hand Surg. 1984;9:231-237. 
13. Acar MA, Güzel Y, Güleç A, Uzer G, Elmadağ M. Clinical comparison of hook plate fixation versus extension block pinning for bony mallet finger: a retrospective comparison study. J Hand Surg Eur Vol. 2015;40:832-839.

14. Handoll HH, Vaghela MV. Interventions for treating mallet finger injuries. Cochrane Database Syst Rev. 2004;3:CD004574.

15. Kalainov DM, Hoepfner PE, Hartigan BJ, Carroll C 4th, Genuario J. Nonsurgical treatment of closed mallet finger fractures. J Hand Surg Am. 2005;30:580586.

16. Garberman SF, Diao E, Peimer CA. Mallet finger: results of early versus delayed closed treatment. J Hand Surg Am. 1994;19:850-852.
17. Shimura H, Wakabayashi Y, Nimura A. A novel closed reduction with extension block and flexion block using Kirschner wires and microscrew fixation for mallet fractures. J Orthop Sci. 2014;19:308-312.

18. Stern PJ, Kastrup JJ. Complications and prognosis oftreatment ofmallet finger. J Hand Surg Am. 1988;13:329-334.

19. Kang HJ, Shin SJ, Kang ES. Complication of operative treatment for mallet fractures of the distal phalanx. J Hand Surg Am. 2001;26:28-31. 